OPEN ACCESS

Edited by:

David Cohen,

Université Pierre et Marie

Curie, France

Reviewed by:

Michel Habib,

Aix-Marseille Université, France Johannes Boltze,

University of Warwick,

United Kingdom

*Correspondence:

Hong Fan

fanhongfan@qq.com

Yonggang Zhang

jebm_zhang@yahoo.com

Specialty section:

This article was submitted to

Child and Adolescent Psychiatry,

a section of the journal

Frontiers in Psychiatry

Received: 25 May 2021

Accepted: 28 June 2021

Published: 22 July 2021

Citation:

Zhang S, Fan H and Zhang Y (2021)

The 100 Top-Cited Studies on

Dyslexia Research: A Bibliometric

Analysis. Front. Psychiatry 12:714627.

doi: 10.3389/fpsyt.2021.714627

\section{The 100 Top-Cited Studies on Dyslexia Research: A Bibliometric Analysis}

\author{
Shijie Zhang ${ }^{1}$, Hong Fan ${ }^{1 *}$ and Yonggang Zhang ${ }^{2,3 *}$ \\ ${ }^{1}$ Department of Respiratory and Critical Care Medicine, West China Hospital/West China School of Medicine, Sichuan \\ University, Chengdu, China, ${ }^{2}$ Department of Periodical Press and National Clinical Research Center for Geriatrics, West \\ China Hospital, Sichuan University, Chengdu, China, ${ }^{3}$ Chinese Evidence-Based Medicine Center, West China Hospital, \\ Sichuan University, Chengdu, China
}

Background: Citation analysis is a type of quantitative and bibliometric analytic method designed to rank papers based on their citation counts. Over the last few decades, the research on dyslexia has made some progress which helps us to assess this disease, but a citation analysis on dyslexia that reflects these advances is lacking.

Methods: A retrospective bibliometric analysis was performed using the Web of Science Core Collection database. The 100 top-cited studies on dyslexia were retrieved after reviewing abstracts or full-texts to May 20th, 2021. Data from the 100 top-cited studies were subsequently extracted and analyzed.

Results: The 100 top-cited studies on dyslexia were cited between 245 to 1,456 times, with a median citation count of 345. These studies were published in 50 different journals, with the "Proceedings of the National Academy of Sciences of the United States of America" having published the most $(n=10)$. The studies were published between 1973 and 2012 and the most prolific year in terms of number of publications was 2000. Eleven countries contributed to the 100 top-cited studies, and nearly $75 \%$ articles were either from the USA ( $n=53)$ or United Kingdom $(n=21)$. Eighteen researchers published at least two different studies of the 100 top-cited list as the first author. Furthermore, 71 studies were published as an original research article, 28 studies were review articles, and one study was published as an editorial material. Finally, "Psychology" was the most frequent study category.

Conclusions: This analysis provides a better understanding on dyslexia and may help doctors, researchers, and stakeholders to achieve a more comprehensive understanding of classic studies, new discoveries, and trends regarding this research field, thus promoting ideas for future investigation.

Keywords: dyslexia, bibliometric analysis, top-cited, citation analysis, citation

\section{INTRODUCTION}

Dyslexia is a common learning disorder that affects between 4 and $8 \%$ of children (1-3), and often persists into adulthood $(4,5)$. This neurodevelopmental disorder is characterized by reading and spelling impairments that develop in a context of normal intelligence, educational opportunities, and perceptual abilities $(4,6)$. Reading and spelling abilities can be affected together or separately. 
The learning abilities of children with dyslexia are significantly lower than those of their unaffected pairs of the same age. Generally, difficulties begin to show during the early school years. Dyslexia is a complex multifactorial disorder whose etiology has not been fully elucidated, and it has caused great social and economic burdens. Over the last few decades, the research on dyslexia has made some progress. For example, some studies have shown that dyslexia has a strong genetic background that can affect brain anatomy $(7,8)$ and function $(9,10)$. But a citation analysis on dyslexia that reflects these advances is lacking.

The publication of study results in scientific journals is the most effective strategy to disseminate new research findings. A high number of citations can indicate the potential of a paper to influence the research community and to generate meaningful changes in clinical practice (11). Citation analysis is a type of quantitative and bibliometric analytic method designed to rank papers based on their citation counts. The latest and up-to-date research findings on dyslexia are well-reflected in recent scientific papers (12), particularly in the most cited ones $(13,14)$. By analyzing the most cited studies, especially the 100 top-cited studies, we can gain better insight into the most significant advances made in the field of dyslexia research over the course of the past several decades (15). This retrospective bibliometric approach has been used for many other diseases, such as diabetes (16), endodontics (17), cancer (18). However, to date, no bibliometric analyses have been conducted in the field of dyslexia. Therefore, the aim of the present study was to analyze the 100 top-cited studies in the field of dyslexia.

\section{MATERIALS AND METHODS}

\section{Search Method and Inclusion Criteria}

This retrospective bibliometric analysis was conducted using the Web of Science Core Collection database. The Web of Science Core Collection is a multidisciplinary database with searchable authors and abstracts covering a vast science journal literature (19). It indexes the major journals of more than 170 subject categories, providing access to retrospective data between 1945 and the present (20). On May 20th, 2021, we conducted an exhaustive literature retrieval, regardless of the country of origin, publication year, and language. The only search term used was "dyslexia" and the search results were sorted by the number of citations.

\section{Article Selection}

Two authors independently screened the abstracts or full-texts to identify the 100 top-cited articles about dyslexia. Disagreements were resolved through discussion. Only studies that focused on dyslexia were included in subsequent analyses. Studies that only mentioned dyslexia in passing were excluded.

\section{Data Extraction}

The final list of the 100 top-cited studies on dyslexia was determined by total article citation counts. We extracted the following data for each article: title, authors, journal, language, total citation count, publication year, country, journal impact factor, type of article, and Web of Science subject category. If the reprint author had two or more affiliations from different countries, we used the first affiliation as the country of origin. If one article was listed in more than one subject category, the first category was selected. If one article had more than one author, we selected the first-ranked author as the first author and the last-ranked author as the last-author.

\section{Data Analysis}

SPSS 11.0 (Chicago, IL, USA) was used to count the frequency. We analyzed the following data: citation count, year of publication, country, the first author, journal, language, type of study, and Web of Science subject category.

\section{RESULTS}

\section{Citation Analysis}

The 100 top-cited studies on dyslexia based on total citations are listed in Table 1. The total citation count for these 100 articles combined was 42,222 . The total citation count of per study ranged from 245 to 1,456 times, with a median citation count of 345 . Only 3 studies were cited more than 1,000 times, and the rest of the studies were cited between 100 and 1,000 times. The title of the top-cited study, which also had the largest mean citation per year count $(n=91)$, was "Reading acquisition, developmental dyslexia, and skilled reading across languages: a psycholinguistic grain size theory," which was published by Ziegler et al. in Psychological Bulletin in 2005 (21). The second top-cited study, which also had the second-highest mean citation per year count $(n=80)$, was published by Vellutino et al. (22). In addition, we also identified the 100 top-cited studies on dyslexia based on mean citation per year, whose results were shown in Supplementary Table 1.

\section{Journals}

The different journals of the 100 top-cited studies on dyslexia and their associated impact factors are listed in Table 2. The 100 top-cited studies on dyslexia were published in 50 different journals, with the top three in frequency being "Proceedings of the National Academy of Sciences of the United States of America" $(n=10)$, "Brain" $(n=6)$, and "Journal of Educational Psychology" ( $n=6)$.

The journal with the highest total citation count was "Proceedings of the National Academy of Sciences of the United States of America." However, the highest average citation count per study belonged to the journal "Psychological Bulletin." The journal impact factors of the 100 top-cited studies on dyslexia ranged from 1.315 to 74.699 . Of the 100 top-cited studies, 29 were published in a journal with an impact factor greater than 10 . The standard "CNS" journals, with the exception of "Cell," "Nature," and "Science" published 2 and 3 studies, respectively. Regarding the top four medical journals, while the "New England Journal of Medicine" and "Lancet" published 2 studies each, no top-cited study was published by the "Journal of the American Medical Association" or the "British Medical Journal." 
TABLE 1 | The 100 top-cited studies on dyslexia based on total citations.

\begin{tabular}{|c|c|c|c|c|c|c|c|}
\hline Ranking & Title & Journal & $\begin{array}{l}\text { Total } \\
\text { citation }\end{array}$ & $\begin{array}{l}\text { Publication } \\
\text { year }\end{array}$ & $\begin{array}{l}\text { Mean } \\
\text { citation per } \\
\text { year }\end{array}$ & Country & $\begin{array}{l}\text { Impact factor in } \\
\text { the year of } \\
\text { publication* }\end{array}$ \\
\hline 1 & $\begin{array}{l}\text { Reading acquisition, developmental dyslexia, and skilled } \\
\text { reading across languages: a psycholinguistic grain size } \\
\text { theory }\end{array}$ & Psychological Bulletin & 1,456 & 2005 & 91 & France & 9.746 \\
\hline 2 & $\begin{array}{l}\text { Specific reading disability (dyslexia): what have we } \\
\text { learned in the past four decades? }\end{array}$ & $\begin{array}{l}\text { Journal of Child Psychology and } \\
\text { Psychiatry }\end{array}$ & 1,359 & 2004 & 80 & USA & 2.782 \\
\hline 3 & $\begin{array}{l}\text { The double-deficit hypothesis for the developmental } \\
\text { dyslexias }\end{array}$ & Journal of Educational Psychology & 1,048 & 1999 & 48 & USA & 1.893 \\
\hline 4 & $\begin{array}{l}\text { Rapid automatized naming (ran) - dyslexia differentiated } \\
\text { from other learning-disabilities }\end{array}$ & Neuropsychologia & 970 & 1976 & 22 & USA & $N / A$ \\
\hline 5 & $\begin{array}{l}\text { Developmental dyslexia- } 4 \text { consecutive patients with } \\
\text { cortical anomalies }\end{array}$ & Annals of Neurology & 955 & 1985 & 27 & USA & $N / A$ \\
\hline 6 & A definition of dyslexia & Annals of Dyslexia & 863 & 2003 & 48 & USA & 1.261 \\
\hline 7 & $\begin{array}{l}\text { Theories of developmental dyslexia: insights from a } \\
\text { multiple case study of dyslexic adults }\end{array}$ & Brain & 832 & 2003 & 46 & France & 7.967 \\
\hline 8 & $\begin{array}{l}\text { To see but not to read; the magnocellular theory of } \\
\text { dyslexia }\end{array}$ & Trends in Neurosciences & 724 & 1997 & 30 & UK & 17.084 \\
\hline 9 & $\begin{array}{l}\text { Developmental dyslexia and specific language } \\
\text { impairment: same or different? }\end{array}$ & Psychological Bulletin & 698 & 2004 & 41 & UK & 7.701 \\
\hline 10 & $\begin{array}{l}\text { Physiological and anatomical evidence for a } \\
\text { magnocellular defect in developmental dyslexia }\end{array}$ & $\begin{array}{l}\text { Proceedings of the National Academy of } \\
\text { Sciences of the United States of America }\end{array}$ & 668 & 1991 & 22 & USA & $N / A$ \\
\hline 11 & Dyslexia: cultural diversity and biological unity & Science & 665 & 2001 & 33 & Italy & 23.329 \\
\hline 12 & Varieties of developmental dyslexia & Cognition & 635 & 1993 & 23 & Australia & $N / A$ \\
\hline 13 & $\begin{array}{l}\text { Disruption of posterior brain systems for reading in } \\
\text { children with developmental dyslexia }\end{array}$ & Biological Psychiatry & 631 & 2002 & 33 & USA & 5.915 \\
\hline 14 & $\begin{array}{l}\text { Phonology, reading acquisition, and dyslexia: insights } \\
\text { from connectionist models }\end{array}$ & Psychological Review & 598 & 1999 & 27 & USA & 6.803 \\
\hline 15 & $\begin{array}{l}\text { Functional disruption in the organization of the brain for } \\
\text { reading in dyslexia }\end{array}$ & $\begin{array}{l}\text { Proceedings of the National Academy of } \\
\text { Sciences of the United States of America }\end{array}$ & 598 & 1998 & 26 & USA & 9.821 \\
\hline 16 & $\begin{array}{l}\text { Deep dyslexia-a case-study of connectionist } \\
\text { neuropsychology }\end{array}$ & Cognitive Neuropsychology & 586 & 1993 & 21 & USA & $N / A$ \\
\hline 17 & $\begin{array}{l}\text { Intensive remedial instruction for children with severe } \\
\text { reading disabilities: immediate and long-term outcomes } \\
\text { from two Instructional approaches }\end{array}$ & Journal of Learning Disabilities & 550 & 2001 & 28 & USA & 1.333 \\
\hline 18 & $\begin{array}{l}\text { Cognitive profiles of difficult-to-remediate and readily } \\
\text { remediated poor readers: early intervention as a vehicle } \\
\text { for distinguishing between cognitive and experiential } \\
\text { deficits as basic causes of specific reading disability }\end{array}$ & Journal of Educational Psychology & 537 & 1996 & 21 & USA & $N / A$ \\
\hline 19 & Developmental dyslexia: the cerebellar deficit hypothesis & Trends in Neurosciences & 511 & 2001 & 26 & UK & 16.475 \\
\hline 20 & $\begin{array}{l}\text { Neural deficits in children with dyslexia ameliorated by } \\
\text { behavioral remediation: evidence from functional MRI }\end{array}$ & $\begin{array}{l}\text { Proceedings of the National Academy of } \\
\text { Sciences of the United States of America }\end{array}$ & 496 & 2003 & 28 & USA & 10.272 \\
\hline
\end{tabular}




Total Publication

Mean

Country

Impact factor in

citation

year

citation pear
year

the year of

$21 \quad$ Developmental dyslexia-diagnostic approach based on

3 atypical reading-spelling patterns

Developmental Medicine and Child

492

1973

10

USA

publication*

22 The evidence for a temporal processing deficit linked to dyslexia: a review

23 Current concepts-dyslexia

24 What is special about face recognition? Nineteen experiments on a person with visual object agnosia and

Psychonomic Bulletin \& Review

New England Journal of Medicine

19

Canada

N/A

dyslexia but normal face recognition

25 Abnormal processing of visual motion in dyslexia

Nature

revealed by functional brain imaging

26 Developmental dyslexia: specific phonological deficit or general sensorimotor dysfunction?

$27 \quad$ Persistence of dyslexics phonological awareness deficits

28 Dyslexia (specific reading disability)

29 Evidence that dyslexia may represent the lower tail of a normal-distribution of reading-ability

$30 \quad$ Brain morphology in developmental dystexia and

attention-deficit disorder hyperactivity

Characteristics of developmental dyslexia in a regular

Current Opinion in Neurobiology

Developmental Psychology

Biological Psychiatry

New England Journal of Medicine

Archives of Neurology

Applied Psycholinguistics

Science

Proceedings of the National Academy of Sciences of the United States of America Reading Research Quarterly chromosome-6

33 Functional connectivity of the angular gyrus in normal reading and dyslexia

34 The non-word reading deficit in developmental dyslexia-a review

35 Is developmental dyslexia a disconnection syndrome? Evidence from pet scanning

$36 \quad$ Explicit and implicit processing of words and pseudowords by adult developmental dyslexics $-a$ search for wernicke's wortschatz?

37 A temporal sampling framework for developmental dyslexia

38 Lesioning an attractor network-investigations of acquired dyslexia

39 Developmental dyslexia: the visual attention span deficit hypothesis

40 The neurological basis of developmental dyslexia -an overview and working hypothesis
Brain

Brain

Trends in Cognitive Sciences

Psychological Review

Cognition

Brain

USA

20 USA

N/A

28.660

4.844 
TABLE 1 | Continued

\begin{tabular}{|c|c|c|c|c|c|c|c|}
\hline Ranking & Title & Journal & $\begin{array}{l}\text { Total } \\
\text { citation }\end{array}$ & $\begin{array}{l}\text { Publication } \\
\text { year }\end{array}$ & $\begin{array}{l}\text { Mean } \\
\text { citation per } \\
\text { year }\end{array}$ & Country & $\begin{array}{l}\text { Impact factor in } \\
\text { the year of } \\
\text { publication* }\end{array}$ \\
\hline 41 & $\begin{array}{l}\text { Developmental lag vs. deficit models of reading disability: } \\
\text { a longitudinal, individual growth curves analysis }\end{array}$ & Journal of Educational Psychology & 397 & 1996 & 16 & USA & N/A \\
\hline 42 & Word-form dyslexia & Brain & 396 & 1980 & 10 & UK & N/A \\
\hline 43 & $\begin{array}{l}\text { Theoretical links among naming speed, precise timing } \\
\text { mechanisms and orthographic skill in dyslexia }\end{array}$ & Reading and Writing & 391 & 1993 & 14 & Canada & N/A \\
\hline 44 & $\begin{array}{l}\text { Cytoarchitectonic abnormalities in developmental } \\
\text { dyslexia-case-study }\end{array}$ & Annals of Neurology & 391 & 1979 & 9 & USA & N/A \\
\hline 45 & $\begin{array}{l}\text { Cognitive profiles of reading-disability-comparisons of } \\
\text { discrepancy and low achievement definitions }\end{array}$ & Journal of Educational Psychology & 388 & 1994 & 14 & USA & N/A \\
\hline 46 & $\begin{array}{l}\text { Neuropsychological analyses of comorbidity between } \\
\text { reading disability and attention deficit hyperactivity } \\
\text { disorder: in search of the common deficit }\end{array}$ & Developmental Neuropsychology & 387 & 2005 & 24 & USA & 2.443 \\
\hline 47 & $\begin{array}{l}\text { Susceptibility loci for distinct components of } \\
\text { developmental dyslexia on chromosomes } 6 \text { and } 15\end{array}$ & American Journal of Human Genetics & 376 & 1997 & 16 & USA & 10.244 \\
\hline 48 & $\begin{array}{l}\text { The impact of orthographic consistency on dyslexia: a } \\
\text { German-English comparison }\end{array}$ & Cognition & 373 & 1997 & 16 & Austria & 2.973 \\
\hline 49 & $\begin{array}{l}\text { Functional neuroimaging studies of reading and reading } \\
\text { disability (developmental dyslexia) }\end{array}$ & $\begin{array}{l}\text { Mental Retardation and Developmental } \\
\text { Disabilities Research Reviews }\end{array}$ & 358 & 2000 & 17 & USA & 0.800 \\
\hline 50 & Phonemic deficits in developmental dyslexia & $\begin{array}{l}\text { Psychological Research-Psychologische } \\
\text { Forschung }\end{array}$ & 348 & 1981 & 9 & UK & N/A \\
\hline 51 & $\begin{array}{l}\text { Is preschool language impairment a risk factor for } \\
\text { dyslexia in adolescence? }\end{array}$ & $\begin{array}{l}\text { Journal of Child Psychology and } \\
\text { Psychiatry and Allied Disciplines }\end{array}$ & 342 & 2000 & 16 & UK & 2.940 \\
\hline 52 & $\begin{array}{l}\text { Dyslexia: a deficit in visuo-spatial attention, not in } \\
\text { phonological processing }\end{array}$ & Trends in Cognitive Sciences & 340 & 2010 & 31 & Australia & 9.686 \\
\hline 53 & $\begin{array}{l}\text { Are specific language impairment and dyslexia distinct } \\
\text { disorders? }\end{array}$ & $\begin{array}{l}\text { Journal of Speech Language and Hearing } \\
\text { Research }\end{array}$ & 336 & 2005 & 21 & USA & 1.725 \\
\hline 54 & $\begin{array}{l}\text { Impaired processing of rapid stimulus sequences in } \\
\text { dyslexia }\end{array}$ & Trends in Cognitive Sciences & 336 & 2001 & 17 & Finland & 11.606 \\
\hline 55 & $\begin{array}{l}\text { Amplitude envelope onsets and developmental dyslexia: } \\
\text { a new hypothesis }\end{array}$ & $\begin{array}{l}\text { Proceedings of the National Academy of } \\
\text { Sciences of the United States of America }\end{array}$ & 329 & 2002 & 17 & UK & 10.700 \\
\hline 56 & $\begin{array}{l}\text { Rapid automatized naming (ran) and reading fluency: } \\
\text { implications for understanding and treatment of reading } \\
\text { disabilities }\end{array}$ & Annual Review of Psychology & 328 & 2012 & 36 & USA & 15.265 \\
\hline 57 & Automaticity - a new framework for dyslexia research & Cognition & 319 & 1990 & 10 & UK & N/A \\
\hline 58 & $\begin{array}{l}\text { Family risk of dyslexia is continuous: individual } \\
\text { differences in the precursors of reading skill }\end{array}$ & Child Development & 310 & 2003 & 17 & UK & 3.324 \\
\hline 59 & $\begin{array}{l}\text { Predicting dyslexia from kindergarten: the importance of } \\
\text { distinctness of phonological representations of lexical } \\
\text { items }\end{array}$ & Reading Research Quarterly & 309 & 1998 & 13 & Denmark & 1.541 \\
\hline
\end{tabular}


TABLE 1 | Continued

\begin{tabular}{|c|c|c|c|c|c|c|c|}
\hline Ranking & Title & Journal & $\begin{array}{l}\text { Total } \\
\text { citation }\end{array}$ & $\begin{array}{l}\text { Publication } \\
\text { year }\end{array}$ & $\begin{array}{l}\text { Mean } \\
\text { citation per } \\
\text { year }\end{array}$ & Country & $\begin{array}{l}\text { Impact factor in } \\
\text { the year of } \\
\text { publication }\end{array}$ \\
\hline 60 & $\begin{array}{l}\text { Sensitivity to dynamic auditory and visual stimuli predicts } \\
\text { non-word reading ability in both dyslexic and normal } \\
\text { readers }\end{array}$ & Current Biology & 303 & 1998 & 13 & UK & 7.855 \\
\hline 61 & $\begin{array}{l}\text { Dyslexia in children and young-adults-3 independent } \\
\text { neuropsychological syndromes }\end{array}$ & $\begin{array}{l}\text { Developmental Medicine and Child } \\
\text { Neurology }\end{array}$ & 303 & 1975 & 7 & USA & N/A \\
\hline 62 & $\begin{array}{l}\text { Neural systems for compensation and persistence: } \\
\text { young adult outcome of childhood reading disability }\end{array}$ & Biological Psychiatry & 301 & 2003 & 17 & USA & 6.039 \\
\hline 63 & On the bases of two subtypes of development dyslexia & Cognition & 299 & 1996 & 12 & USA & $\mathrm{N} / \mathrm{A}$ \\
\hline 64 & $\begin{array}{l}\text { Relations among speech, language, and reading } \\
\text { disorders }\end{array}$ & Annual Review of Psychology & 295 & 2009 & 25 & USA & 22.750 \\
\hline 65 & Neurobiological studies of reading and reading disability & Journal of Communication Disorders & 295 & 2001 & 15 & USA & 0.640 \\
\hline 66 & $\begin{array}{l}\text { Word-recognition skills of adults with childhood } \\
\text { diagnoses of dyslexia }\end{array}$ & Developmental Psychology & 295 & 1990 & 10 & Canada & N/A \\
\hline 67 & $\begin{array}{l}\text { Biological abnormality of impaired reading is constrained } \\
\text { by culture }\end{array}$ & Nature & 294 & 2004 & 17 & China & 32.182 \\
\hline 68 & Developmental dyslexia & Lancet & 293 & 2004 & 17 & France & 21.713 \\
\hline 69 & $\begin{array}{l}\text { Subtypes of reading disability: variability around a } \\
\text { phonological core }\end{array}$ & Journal of Educational Psychology & 291 & 1998 & 13 & USA & 1.595 \\
\hline 70 & $\begin{array}{l}\text { Understanding Chinese developmental dyslexia: } \\
\text { morphological awareness as a core cognitive construct }\end{array}$ & Journal of Educational Psychology & 290 & 2006 & 19 & China & 2.025 \\
\hline 71 & $\begin{array}{l}\text { On the specifics of specific reading disability and specific } \\
\text { language impairment }\end{array}$ & $\begin{array}{l}\text { Journal of Child Psychology and } \\
\text { Psychiatry and Allied Disciplines }\end{array}$ & 286 & 2000 & 14 & UK & 2.940 \\
\hline 72 & $\begin{array}{l}\text { DCDC2 is associated with reading disability and } \\
\text { modulates neuronal development in the brain }\end{array}$ & $\begin{array}{l}\text { Proceedings of the National Academy of } \\
\text { Sciences of the United States of America }\end{array}$ & 285 & 2005 & 18 & USA & 10.231 \\
\hline 73 & $\begin{array}{l}\text { Dyslexia: a new synergy between education and } \\
\text { cognitive neuroscience }\end{array}$ & Science & 284 & 2009 & 24 & USA & 29.747 \\
\hline 74 & Toward a definition of dyslexia & Annals of Dyslexia & 284 & 1995 & 11 & USA & $\mathrm{N} / \mathrm{A}$ \\
\hline 75 & $\begin{array}{l}\text { Estimating the risk of future reading difficulties in } \\
\text { kindergarten children: a research-based model and its } \\
\text { clinical implementation }\end{array}$ & $\begin{array}{l}\text { Language Speech and Hearing Services in } \\
\text { Schools }\end{array}$ & 282 & 2001 & 14 & USA & 0.558 \\
\hline 76 & $\begin{array}{l}\text { Early reading development in children at family risk for } \\
\text { dyslexia }\end{array}$ & Child Development & 281 & 2001 & 14 & USA & 2.583 \\
\hline 77 & Developmental dyslexia & Lancet & 279 & 2012 & 31 & USA & 39.060 \\
\hline 78 & $\begin{array}{l}\text { Functional abnormalities in the dyslexic brain: a } \\
\text { quantitative meta-analysis of neuroimaging studies }\end{array}$ & Human Brain Mapping & 278 & 2009 & 23 & Austria & 6.256 \\
\hline 79 & $\begin{array}{l}\text { Contrast sensitivity and coherent motion detection } \\
\text { measured at photopic luminance levels in dyslexics and } \\
\text { controls }\end{array}$ & Vision Research & 276 & 1995 & 11 & UK & N/A \\
\hline 80 & $\begin{array}{l}\text { Evidence for aberrant auditory anatomy in developmental } \\
\text { dyslexia }\end{array}$ & $\begin{array}{l}\text { Proceedings of the National Academy of } \\
\text { Sciences of the United States of America }\end{array}$ & 275 & 1994 & 10 & USA & $\mathrm{N} / \mathrm{A}$ \\
\hline
\end{tabular}




Total

Total

Publication

Mean

Mean
citation per
year

Country
year

$81 \quad$ Psychiatric comorbidity in children and adolescents with

Journal of Child Psychology and

274

Psychiatry

Pediatrics

Persistence of dyslexia:
study at adolescence

83 Functional and morphometric brain dissociation between dyslexia and reading ability

84 Dyslexia-specific brain activation profile becomes normal following successful remedial training

85 A candidate gene for developmental dyslexia encodes a nuclear tetratricopeptide repeat domain protein dynamically regulated in brain

$86 \quad$ Neural systems predicting long-term outcome in dyslexia

87 Developmental dyslexia in women-neuropathological findings in 3 patients

88 MRl evaluation of the size and symmetry of the planum-temporale in adolescents with developmental dyslexia

Paying attention to reading: the neurobiology of reading and dyslexia

$90 \quad$ Impaired visual word processing in dyslexia revealed with magnetoencephalography

91 Developmental dyslexia in different languages: language-specific or universal?

92 The magnocellular deficit theory of dyslexia: the evidence from contrast sensitivity

93 Disrupted neural responses to phonological and orthographic processing in dyslexic children: an fMRI study

Proceedings of the National Academy of Sciences of The United States of America Neurology

Proceedings of the National Academy of Sciences of The United States of America

Proceedings of the National Academy of Sciences of the United States of America Annals of Neurology

Brain and Language

Development and Psychopathology

Annals of Neurology

Journal of Experimental Child Psychology

Vision Research

Neuroreport

Psychological Science

269

268

264

(1)

and ar in developmental dyslexia: task-specific differences in functional connectivity within posterior cortex

95 Phonological awareness deficits in developmental dyslexia and the phonological representations hypothesis

13

USA
the year of publication*

2000

12

2.940

$$
1999
$$

12

69

19

USA

9.598

2002

14

USA

$$
2003
$$

15

Finland

Developmental dyslexia: genetic dissection of a complex

Nature Reviews Neuroscience 


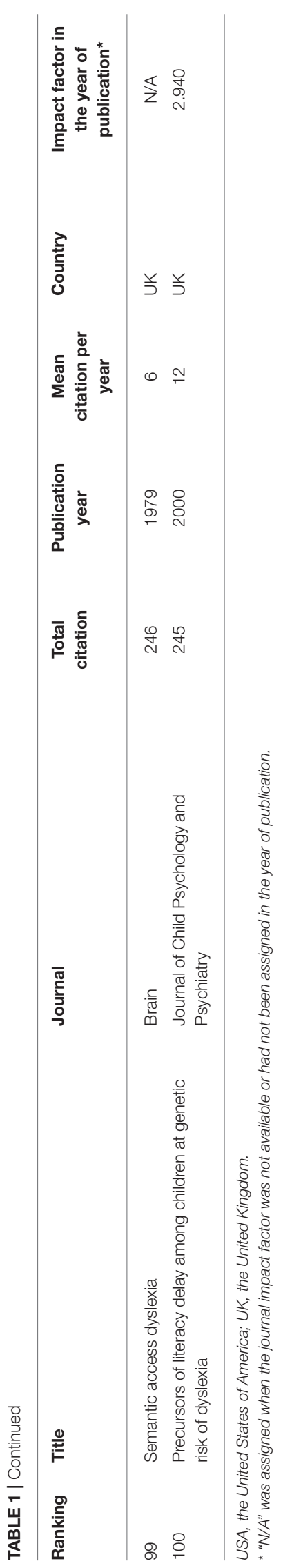

\section{Language and Year of Publication}

The 100 top-cited studies on dyslexia were all published in English and were published between 1973 [by Boder et al. (23)] and 2012 [by Norton et al. (24) and Peterson et al. (25)] (Table 3). The most productive years were 2000, 2001 and 2003, with 9, 8 and 8 published articles, respectively. The year of 2003 had the most total citations with a total count of 3,788 and an average citation count per study of 474 .

\section{Countries and Authors}

Eleven countries contributed articles to the 100 top-cited studies on dyslexia (Table 4). Most of the articles were from the USA ( $n$ $=53)$, United Kingdom $(n=21)$, Canada $(n=7)$, and France $(n$ $=6)$. In addition, the USA had the highest total citation count $(23,129)$, and Italy had the highest average citation count per study (665).

As shown in Table 5, there were 18 first-authors and 13 lastauthors who published more than one of the 100 top-cited studies on dyslexia. Among them, Shaywitz SE published the most top 100 articles $(n=7)$ on dyslexia as the first author, followed by Galaburda AM $(n=3)$ and Pugh KR $(n=3)$. And for the last author, 8 studies of the 100 top-cited studies on dyslexia research were published by Shaywitz BA who was the most productive.

\section{Publication Type and Web of Science Subject Categories}

As shown in Table 6, there were 71 studies in the form of an original research article, 28 studies in the form of a review article, and one study in the form of an editorial material publication. The total citation counts for each publication type were $27,812,13,899$, and 511, respectively. Although the type of original research article had the highest total citation count, it had the lowest average citation count per study. In addition, a total of $12 \mathrm{Web}$ of Science subject categories were extracted. Among them, "Psychology" was the most frequent category associated with studies [35], followed by "Clinical Neurology" [15], and "Multidisciplinary Sciences" [15], "Neurosciences" [12], and "Education" [6]. Consistent with the number of studies, the subject categories of "Psychology" and "Clinical Neurology" also had the highest total citation counts (15,683 and 6,427, respectively). The "Behavioral Sciences" subject category had the highest average citation count.

\section{DISCUSSION}

Although retrospective bibliometric approach has been conducted in many other diseases, to our knowledge, no citation analyses have examined publications on dyslexia. Therefore, this study is the first comprehensive analysis summarizing several features of the most influential studies on dyslexia. It has been suggested that a highly cited study can be considered as a milestone study in a related field and has the potential to generate meaningful changes in clinical practice (26). We believe that the present analysis of the 100 top-cited studies on dyslexia may be beneficial to the research community for the following reasons. First, the present study not only provides a historical projection of the scientific progress with regards to dyslexia research, but it 
TABLE 2 | Journals of the 100 top-cited studies on dyslexia.

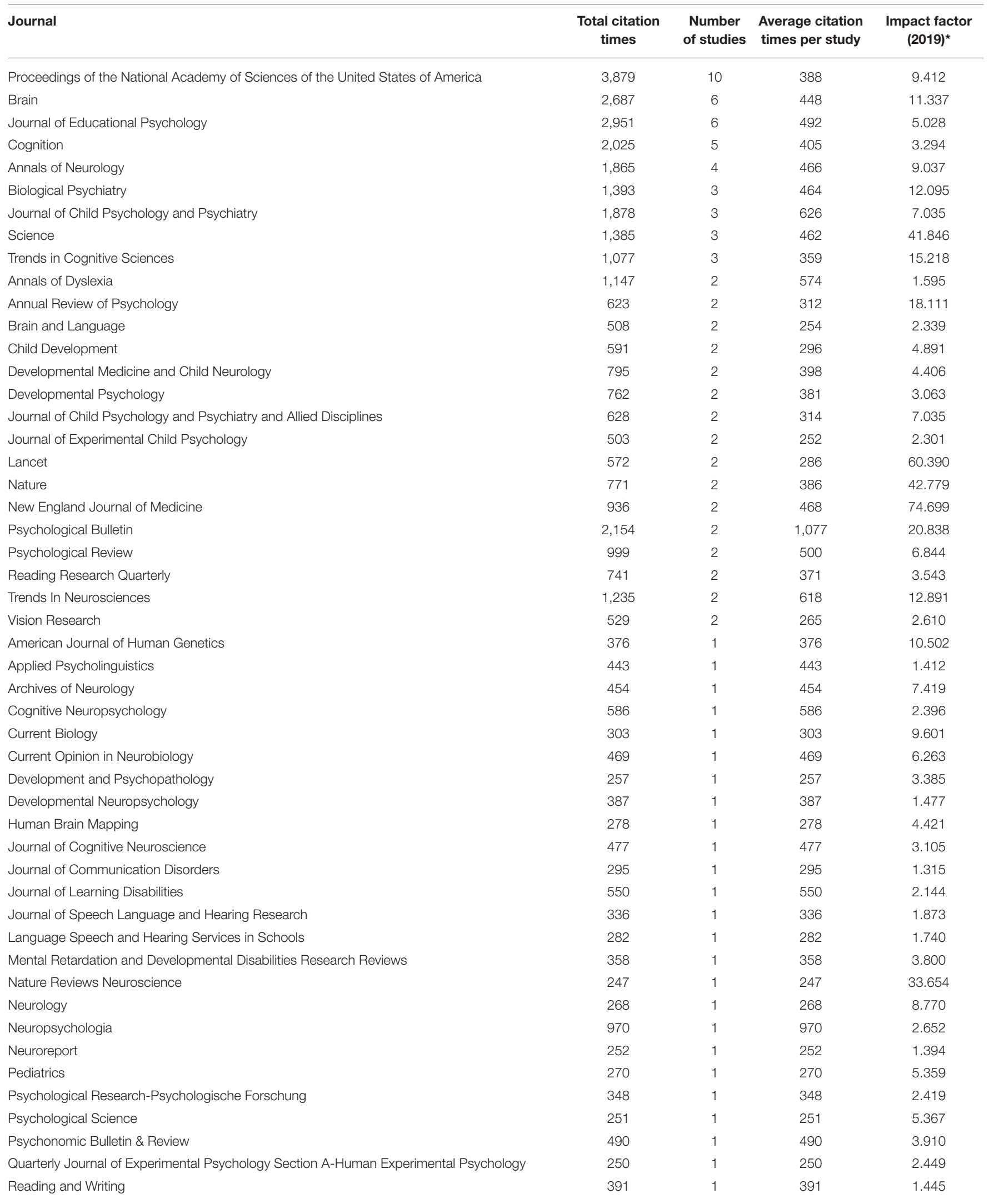

*Impact factors were extracted from the journal citation report of 2019. If the journal did not have an impact factor for 2019, its impact factor was expressed for the last year. 
TABLE 3 | Publication year of the 100 top-cited studies on dyslexia.

\begin{tabular}{|c|c|c|c|}
\hline Year & $\begin{array}{l}\text { Number of } \\
\text { studies }\end{array}$ & $\begin{array}{l}\text { Total citation } \\
\text { times }\end{array}$ & $\begin{array}{c}\text { Average citation } \\
\text { times }\end{array}$ \\
\hline 2000 & 9 & 2,655 & 295 \\
\hline 2001 & 8 & 3,172 & 397 \\
\hline 2003 & 8 & 3,788 & 474 \\
\hline 1996 & 6 & 2,379 & 397 \\
\hline 1998 & 6 & 2,410 & 402 \\
\hline 1990 & 5 & 1,590 & 318 \\
\hline 1997 & 5 & 2,200 & 440 \\
\hline 2005 & 5 & 2,925 & 585 \\
\hline 1993 & 4 & 2,055 & 514 \\
\hline 1999 & 4 & 2,319 & 580 \\
\hline 2002 & 4 & 1,475 & 369 \\
\hline 2004 & 4 & 2,644 & 661 \\
\hline 1992 & 3 & 1,358 & 453 \\
\hline 1994 & 3 & 1,099 & 366 \\
\hline 1995 & 3 & 1,050 & 350 \\
\hline 2009 & 3 & 857 & 286 \\
\hline 1979 & 2 & 637 & 319 \\
\hline 1991 & 2 & 1,069 & 535 \\
\hline 2007 & 2 & 668 & 334 \\
\hline 2011 & 2 & 664 & 332 \\
\hline 2012 & 2 & 607 & 304 \\
\hline 1973 & 1 & 492 & 492 \\
\hline 1975 & 1 & 303 & 303 \\
\hline 1976 & 1 & 970 & 970 \\
\hline 1980 & 1 & 396 & 396 \\
\hline 1981 & 1 & 348 & 348 \\
\hline 1983 & 1 & 250 & 250 \\
\hline 1985 & 1 & 955 & 955 \\
\hline 2006 & 1 & 290 & 290 \\
\hline 2008 & 1 & 257 & 257 \\
\hline 2010 & 1 & 340 & 340 \\
\hline
\end{tabular}

also shows associated research trends and gaps in the field (27). Second, our findings provide critical quantitative information about how both the classic studies and recent advancements in the field have improved our understanding of dyslexia (28). Third, the present analysis may help journal editors, funding agencies, and reviewers critically evaluate studies and funding applications (28).

Our analysis discovered that the 100 top-cited studies on dyslexia were published in 50 different journals. This may reflect the fact that the 100 top-cited studies on dyslexia were very multidisciplinary in nature, unlike the top studies of other fields (e.g., psoriatic arthritis) where there is a more inherent researcher bias for journal selection (29). Of the 100 top-cited studies, 29 were published in a journal with an impact factor $>10$, and 62 studies were published in journal with an impact factor $>5$. However, there were only five studies published in the standard "CNS" journals and only four published in the top four medical journals, which suggests that most dyslexia researchers are more
TABLE 4 | Countries of the 100 top-cited studies on dyslexia.

\begin{tabular}{lccc}
\hline Country* & $\begin{array}{c}\text { Number of } \\
\text { studies }\end{array}$ & $\begin{array}{c}\text { Total citation } \\
\text { times }\end{array}$ & $\begin{array}{c}\text { Average citation } \\
\text { times }\end{array}$ \\
\hline USA & 53 & 23,129 & 436 \\
UK & 21 & 7,728 & 368 \\
Canada & 7 & 2,919 & 417 \\
France & 6 & 3,702 & 617 \\
Austria & 3 & 1,094 & 365 \\
Finland & 3 & 857 & 286 \\
Australia & 2 & 975 & 488 \\
China & 2 & 584 & 292 \\
Denmark & 1 & 309 & 309 \\
Italy & 1 & 665 & 665 \\
Norway & 1 & 260 & 260
\end{tabular}

USA, the United States of America; UK, the United Kingdom.

*The country distribution of 100 top-cited studies on dyslexia research were extracted from the corresponding author.

TABLE 5 | Authors with at least two first-author or last-author publications in the 100 top-cited studies on dyslexia.

\begin{tabular}{|c|c|c|c|}
\hline \multicolumn{2}{|c|}{ First-author } & \multicolumn{2}{|c|}{ Last-author } \\
\hline Name & $\begin{array}{c}\text { Number of } \\
\text { studies }\end{array}$ & Name & $\begin{array}{c}\text { Number of } \\
\text { studies }\end{array}$ \\
\hline Shaywitz SE & 7 & Shaywitz BA & 8 \\
\hline Galaburda AM & 3 & Frith $U$ & 5 \\
\hline Pugh KR & 3 & Gabrieli JDE & 5 \\
\hline Bruck M & 2 & Gore JC & 4 \\
\hline Catts HW & 2 & Shallice T & 4 \\
\hline Goswami U & 2 & Goswami U & 3 \\
\hline Hoeft F & 2 & Snowling MJ & 3 \\
\hline Lyon GR & 2 & Bruck M & 2 \\
\hline Nicolson Rl & 2 & Defries JC & 2 \\
\hline Pennington BF & 2 & Galaburda AM & 2 \\
\hline Paulesu E & 2 & Pennington BF & 2 \\
\hline Ramus F & 2 & Wimmer H & 2 \\
\hline Snowling MJ & 2 & Wolf M & 2 \\
\hline Temple E & 2 & & \\
\hline Vellutino FR & 2 & & \\
\hline Warrington EK & 2 & & \\
\hline Willcutt EG & 2 & & \\
\hline Ziegler JC & 2 & & \\
\hline
\end{tabular}

inclined to choose the most influential journals in their respective professional fields when submitting articles (30). This is in marked contrast with some other fields (e.g. vaccines), where the majority of top-cited articles are published in either the standard "CNS" journals or in the top four medical journals (15). Several other factors, such as the review turnaround time, likelihood of manuscript acceptance, publication costs, journal publication frequency, will all invariably also affect a researcher's journal selection $(13,20)$. 
TABLE 6 | Type of study and subject categories for the 100 top-cited studies on dyslexia.

\begin{tabular}{|c|c|c|c|}
\hline Variable & $\begin{array}{l}\text { Number } \\
\text { of studies }\end{array}$ & $\begin{array}{l}\text { Total citation } \\
\text { times }\end{array}$ & $\begin{array}{l}\text { Average citation } \\
\text { times per study }\end{array}$ \\
\hline \multicolumn{4}{|l|}{ Type of study } \\
\hline Article & 71 & 27,812 & 392 \\
\hline Review & 28 & 13,899 & 496 \\
\hline Editorial Material & 1 & 511 & 511 \\
\hline \multicolumn{4}{|c|}{ Web of Science categories* } \\
\hline Psychology & 35 & 15,683 & 448 \\
\hline Clinical Neurology & 15 & 6,427 & 428 \\
\hline Multidisciplinary Sciences & 15 & 6,035 & 402 \\
\hline Neurosciences & 12 & 4,880 & 407 \\
\hline Education & 6 & 2,829 & 472 \\
\hline $\begin{array}{l}\text { Audiology \& } \\
\text { Speech-Language } \\
\text { Pathology }\end{array}$ & 5 & 1,421 & 284 \\
\hline Behavioral Sciences & 4 & 2,047 & 512 \\
\hline Medicine & 4 & 1,508 & 377 \\
\hline $\begin{array}{l}\text { Biochemistry \& Molecular } \\
\text { Biology }\end{array}$ & 1 & 303 & 303 \\
\hline Genetics \& Heredity & 1 & 376 & 376 \\
\hline Linguistics & 1 & 443 & 443 \\
\hline Pediatrics & 1 & 270 & 270 \\
\hline
\end{tabular}

*Web of Science subject categories were extracted from the Web of Science. If one article was listed in more than one category, the first category was used for data analysis.

According to the results of our analysis, nearly $80 \%$ of the 100 top-cited studies on dyslexia were published between 1990 and 2005, and the years of 2000 was found to have the most publications. The increase of landmark publications between 1990 and 2005 might reflect an increase in the interest in dyslexia research or that researchers had made some important scientific breakthroughs during this time period. All the top-cited studies on dyslexia were published in English, likely because English is the most commonly used language for knowledge dissemination in the world.

The top countries with regards to total citation count and number of papers in the top 100 list were the USA $(n=53)$ and United Kingdom $(n=21)$, which accounted for $\sim 75 \%$ of the 100 top-cited studies. The USA published the most studies from the list, and this is probably because some of the world's top research centers are located in the USA and likely also the USA receives more research funding (31). Furthermore, the most prolific firstauthor (Shaywitz SE) and last-author (Shaywitz BA) were also from the USA. It is also worth mentioning that China had two studies on the top 100 list, which attests to the improvement of our national scientific research community with regards to knowledge dissemination.

In the present study, there were more original research articles $(n=71)$ than review articles $(n=28)$, but the latter had higher average citation counts per study. These results indicate that even though researchers pay significant attention to new findings on dyslexia, they regularly use information from review articles to convey relevant points in their own papers. We found that "Psychology" was the most frequent subject category associated with the top 100 articles, which indicates that researchers have been working to find effective treatments for people with dyslexia and that research in this field will continue to progress.

Like with other bibliometric analyses, there are some study limitations that should be highlighted. First, the 100 top-cited studies were extracted from the Web of Science Core Collection, which might have excluded some top-cited studies from other databases, such as Scopus and Google Scholar. Second, there was no citation data for recently published studies. Third, selfcitations might have substantially influenced the results of the citation analysis. Moreover, this was a cross-sectional study, which implies that the identified 100 top-cited studies could change in the future. Despite these limitations, this descriptive bibliometric study could contribute new information about the scientific interest in dyslexia.

In conclusion, the present analysis is the first analysis to recognize the 100 top-cited studies in the field of dyslexia. This analysis provides a better understanding on dyslexia and may help doctors, researchers, and stakeholders to achieve a more comprehensive understanding of classic studies, new discoveries, and trends regarding this research field. As new data continue to emerge, this bibliometric analysis will become an important quantitative instrument to ascertain the overall direction of a given field, thus promoting ideas for future investigation.

\section{DATA AVAILABILITY STATEMENT}

The original contributions presented in the study are included in the article/Supplementary Material, further inquiries can be directed to the corresponding author/s.

\section{AUTHOR CONTRIBUTIONS}

$\mathrm{YZ}$ and HF designed the study. SZ and $\mathrm{YZ}$ acquired the data and performed statistical analyses. SZ, YZ, and HF drafted the manuscript. All authors critically revised the article and approved the final version of the manuscript.

\section{FUNDING}

This study was partly supported by National Clinical Research Center for Geriatrics, West China Hospital, Sichuan University (Z2018B016).

\section{SUPPLEMENTARY MATERIAL}

The Supplementary Material for this article can be found online at: https://www.frontiersin.org/articles/10.3389/fpsyt. 2021.714627/full\#supplementary-material 


\section{REFERENCES}

1. Fortes IS, Paula CS, Oliveira MC, Bordin IA, de Jesus Mari J, Rohde LA. A cross-sectional study to assess the prevalence of DSM-5 specific learning disorders in representative school samples from the second to sixth grade in Brazil. Eur Child Adolesc Psychiatry. (2016) 25:195-207. doi: 10.1007/s00787-015-0708-2

2. Landerl K, Moll K. Comorbidity of learning disorders: prevalence and familial transmission. J Child Psychol Psychiatry Allied Discipl. (2010) 51:287-94. doi: 10.1111/j.1469-7610.2009.02164.x

3. Castillo A, Gilger JW. Adult perceptions of children with dyslexia in the USA. Ann Dyslexia. (2018) 68:203-17. doi: 10.1007/s11881-018-0163-0

4. Peterson RL, Pennington BF. Developmental dyslexia. Ann Rev Clin Psychol. (2015) 11:283-307. doi: 10.1146/annurev-clinpsy-032814-112842

5. Cavalli E, Colé P, Brèthes H, Lefevre E, Lascombe S, Velay JL. E-book reading hinders aspects of long-text comprehension for adults with dyslexia. Ann Dyslexia. (2019) 69:243-59. doi: 10.1007/s11881-019-00182-w

6. Wang LC, Liu D, Xu Z. Distinct effects of visual and auditory temporal processing training on reading and reading-related abilities in Chinese children with dyslexia. Ann Dyslexia. (2019) 69:166-85. doi: 10.1007/s11881-019-00176-8

7. Skeide MA, Kraft I, Müller B, Schaadt G, Neef NE, Brauer J, et al. NRSN1 associated grey matter volume of the visual word form area reveals dyslexia before school. Brain. (2016) 139:2792-803. doi: 10.1093/brain/aww153

8. Kraft I, Schreiber J, Cafiero R, Metere R, Schaadt G, Brauer J, et al. Predicting early signs of dyslexia at a preliterate age by combining behavioral assessment with structural MRI. NeuroImage. (2016) 143:378-86. doi: 10.1016/j.neuroimage.2016.09.004

9. Neef NE, Müller B, Liebig J, Schaadt G, Grigutsch M, Gunter TC, et al. Dyslexia risk gene relates to representation of sound in the auditory brainstem. Dev Cogn Neurosci. (2017) 24:63-71. doi: 10.1016/j.dcn.2017.01.008

10. Männel C, Meyer L, Wilcke A, Boltze J, Kirsten H, Friederici AD. Working-memory endophenotype and dyslexia-associated genetic variant predict dyslexia phenotype. Cortex. (2015) 71:291-305. doi: 10.1016/j.cortex.2015.06.029

11. Perazzo MF, Otoni ALC, Costa MS, Granville-Granville AF, Paiva SM, Martins-Júnior PA. The top 100 most-cited papers in paediatric dentistry journals: a bibliometric analysis. Int J Paediatr Dentist. (2019) 29:692-711. doi: 10.1111/ipd.12563

12. Daley EM, Vamos CA, Zimet GD, Rosberger Z, Thompson EL, Merrell L. The feminization of HPV: reversing gender biases in US human papillomavirus vaccine policy. Am J Public Health. (2016) 106:983-4. doi: 10.2105/AJPH.2016.303122

13. Kolkailah AA, Fugar S, Vondee N, Hirji SA, Okoh AK, Ayoub A, et al. Bibliometric analysis of the top 100 most cited articles in the first 50 years of heart transplantation. Am J Cardiol. (2019) 123:175-86. doi: 10.1016/j.amjcard.2018.09.010

14. Zhao X, Guo L, Lin Y, Wang H, Gu C, Zhao L, et al. The top 100 most cited scientific reports focused on diabetes research. Acta Diabetol. (2016) 53:13-26. doi: 10.1007/s00592-015-0813-1

15. Zhang Y, Quan L, Xiao B, Du L. The 100 top-cited studies on vaccine: a bibliometric analysis. Hum Vacc Immunother. (2019) 15:3024-31. doi: 10.1080/21645515.2019.1614398

16. Beshyah WS, Beshyah SA. Bibliometric analysis of the literature on Ramadan fasting and diabetes in the past three decades (1989-2018). Diabetes Res Clin Pract. (2019) 151:313-22. doi: 10.1016/j.diabres.2019.03.023
17. Adnan S, Ullah R. Top-cited articles in regenerative endodontics: a bibliometric analysis. J Endodontics. (2018) 44:1650-64. doi: 10.1016/j.joen.2018.07.015

18. Gao Y, Shi S, Ma W, Chen J, Cai Y, Ge L, et al. Bibliometric analysis of global research on PD-1 and PD-L1 in the field of cancer. Int Immunopharmacol. (2019) 72:374-84. doi: 10.1016/j.intimp.2019.03.045

19. Yu T, Jiang Y, Gamber M, Ali G, Xu T, Sun W. Socioeconomic status and selfrated health in China: findings from a cross-sectional study. Medicine. (2019) 98:e14904. doi: 10.1097/MD.0000000000014904

20. Yoon DY, Yun EJ, Ku YJ, Baek S, Lim KJ, Seo YL, et al. Citation classics in radiology journals: the 100 top-cited articles, 1945-2012. AJR Am J Roentgenol. (2013) 201:471-81. doi: 10.2214/AJR.12.10489

21. Ziegler JC, Goswami U. Reading acquisition, developmental dyslexia, and skilled reading across languages: a psycholinguistic grain size theory. Psychol Bull. (2005) 131:3-29. doi: 10.1037/0033-2909.131.1.3

22. Vellutino FR, Fletcher JM, Snowling MJ, Scanlon DM. Specific reading disability (dyslexia): what have we learned in the past four decades? J Child Psychol Psychiatry Allied Discipl. (2004) 45:2-40. doi: 10.1046/j.0021-9630.2003.00305.x

23. Boder E. Developmental dyslexia: a diagnostic approach based on three atypical reading-spelling patterns. Dev Med Child Neurol. (1973) 15:663-87. doi: 10.1111/j.1469-8749.1973.tb05180.x

24. Norton ES, Wolf M. Rapid automatized naming (RAN) and reading fluency: implications for understanding and treatment of reading disabilities. Ann Rev Psychol. (2012) 63:427-52. doi: 10.1146/annurev-psych-120710-100431

25. Peterson RL, Pennington BF. Developmental dyslexia. Lancet. (2012) 379:1997-2007. doi: 10.1016/S0140-6736(12)60198-6

26. Van Noorden R, Maher B, Nuzzo R. The top 100 papers. Nature. (2014) 514:550-3. doi: 10.1038/514550a

27. Fardi A, Kodonas K, Gogos C, Economides N. Top-cited articles in endodontic journals. J Endodontics. (2011) 37:1183-90. doi: 10.1016/j.joen.2011.05.037

28. Gondivkar SM, Sarode SC, Gadbail AR, Gondivkar RS, Choudhary N, Patil S. Citation classics in cone beam computed tomography: the 100 topcited articles. Int J Dentistry. (2018) 2018:9423281. doi: 10.1155/2018/94 23281

29. Berlinberg A, Bilal J, Riaz IB, Kurtzman DJB. The 100 top-cited publications in psoriatic arthritis: a bibliometric analysis. Int J Dermatol. (2019) 58:1023-34. doi: $10.1111 /$ ijd.14261

30. Bullock N, Ellul T, Bennett A, Steggall M, Brown G. The 100 most influential manuscripts in andrology: a bibliometric analysis. Basic Clin Androl. (2018) 28:15. doi: 10.1186/s12610-018-0080-4

31. Shadgan B, Roig M, Hajghanbari B, Reid WD. Top-cited articles in rehabilitation. Arch Phys Med Rehabilit. (2010) 91:806-15. doi: 10.1016/j.apmr.2010.01.011

Conflict of Interest: The authors declare that the research was conducted in the absence of any commercial or financial relationships that could be construed as a potential conflict of interest.

Copyright (c) 2021 Zhang, Fan and Zhang. This is an open-access article distributed under the terms of the Creative Commons Attribution License (CC BY). The use, distribution or reproduction in other forums is permitted, provided the original author(s) and the copyright owner(s) are credited and that the original publication in this journal is cited, in accordance with accepted academic practice. No use, distribution or reproduction is permitted which does not comply with these terms. 